\title{
Smoking and occupation from the European Community Respiratory Health Survey
}

\author{
S A McCurdy, J Sunyer, J-P Zock, J M Antó, M Kogevinas, European Community \\ Respiratory Health Survey Study Group
}

Occup Environ Med 2003;60:643-648

See end of article for authors' affiliations

....................

Correspondence to: Dr S A McCurdy,

Department of

Epidemiology and

Preventive Medicine,

University of California,

Davis, One Shields Ave,

Davis, CA 95616-8638,

USA;

samccurdy@ucdavis.edu

Accepted 11 October 2002

\begin{abstract}
Background: Smoking is among the most important personal and modifiable risk factors for adverse health outcomes. The workplace offers a potentially effective venue for tobacco prevention programmes; identifying occupational groups with high smoking prevalence may assist in targeting such programmes.

Aims: To examine smoking prevalence among occupational groups in the European Union.

Methods: The European Community Respiratory Health Survey (ECRHS), a cross sectional health survey conducted in 1992-93, was used to examine smoking prevalence by occupation among 14565 subjects from 30 centres in 14 participating countries.

Results: There was an approximately twofold range in smoking prevalence by occupation. For occupational groups with at least 50 subjects, the highest smoking prevalence was seen in metal making and treating for men (54.3\%) and cleaners for women (50.7\%). Increased smoking prevalence by occupation persisted after adjustment for age, country, and age at completion of education. Smoking was also increased among occupations with high exposure to mineral dust and gas or fumes.

Conclusions: Smoking rates vary significantly by occupation. Prevention efforts in the workplace should focus on occupations with high smoking prevalence and large employment bases.
\end{abstract}

S moking is widely recognised as the most important modifiable risk factor for numerous adverse health outcomes, including respiratory cancers, heart disease, and stroke. ${ }^{12}$ In the USA, significant progress has been made over past decades in reducing adult smoking prevalence. ${ }^{2}$ Methods for discouraging smoking include educational campaigns, taxation, and regulation. Tobacco control efforts often include workplace restrictions on smoking, which are generally well accepted by employees, even among those who smoke. ${ }^{3}$ Although workplace restrictions have an important role for tobacco control, few data are available on smoking prevalence by occupation-information important for target-

\section{Main messages}

- Smoking prevalence varied approximately twofold among occupations. Prevalence was highest for men among metal, construction, and mining workers and for women among cleaners and hairdressers.

- Smoking prevalence was lowest for men among persons with no stated occupation (including students) and for women among agricultural workers.

- Smoking prevalence increased directly with occupational exposure to mineral dust and gas or fumes.

\section{Policy implications}

- Anti-tobacco programmes should be focused on groups with high smoking prevalence and employee base. For men, these groups include metal, construction, and mining workers. For women, these groups include cleaners and hairdressers.

- Smoking prevalence studies should be conducted periodically to focus anti-tobacco efforts and monitor their effectiveness. ing worksite based tobacco control programmes. While such data are available for the USA, ${ }^{4-7}$ there is little information on smoking by occupation for the European Union and associated countries, where smoking prevalence is significantly higher than in the USA. ${ }^{8}$

The European Community Respiratory Health Survey (ECRHS) has collected information relevant to respiratory health in nations of western European and other areas of the world since 1990. ${ }^{9}$ The purpose of this article is to describe the smoking prevalence among study participants, with a focus on occupation and related exposures.

\section{METHODS}

\section{Population}

The ECHRS methodology has been described previously. ${ }^{9}$ Briefly, it consists of a random sample of the general population, aged 20-44 years, in 33 centres in 11 countries of the European Union, seven centres in five countries of the Cooperation in Science and Technical Research Group of European States, and 15 centres in seven other nations. This report includes 14714 randomly sampled subjects, aged 20-44 years, from 30 centres in 14 countries ( 11 countries of Western Europe, Australia, New Zealand, and the USA), in which occupational data were collected by cross sectional survey in 1992-93. The study was approved by the local institutional ethics committees, and all subjects gave informed consent.

Exposure assignment for smoking, occupation, and occupational exposures

Participating subjects completed a standardised respiratory health questionnaire including information on demographic

Abbreviations: $\mathrm{Cl}$, confidence interval; cpd, cigarettes per day; ECRHS, European Community Respiratory Health Survey 
characteristics, smoking, and occupation. Current smoking was defined as: (a) lifetime consumption of at least 20 packs of cigarettes or at least one cigarette per day or one cigar a week for one year; and (b) affirmation of smoking within the past month.

Occupation was initially coded using 350 categories based on the Office of Population Censuses and Surveys classification scheme ${ }^{10}$; these were subsequently combined into a set of 30 occupational groups for analysis. ${ }^{11}$ We further collapsed three painter categories (spray painters, other painters, and remainder painting) into a single category, yielding a total of 28 categories. A job-exposure matrix was developed by industrial hygienists to evaluate the likely exposures to biologic dust, mineral dust, and gas or fumes. ${ }^{12}$ This categorisation was based on occupational designation (using the initial 350 categories) rather than specific exposure estimates provided by the subject. Exposure assignment for biologic dust, mineral dust, and gases or fumes was not mutually exclusive-that is, individuals could have high exposure to any combination of these agents. Each exposure was categorised as none, low, or high. Occupations associated with high levels of exposure to biologic dust, mineral dust, and gases or fumes are shown in the appendix (see OEM website; www.occenvmed.com).

\section{Data management and analysis}

Data were analysed using STATA 6.0 and 7.0 (STATA Corporation, College Station, TX, USA). Smoking prevalence and exact binomial $95 \%$ confidence intervals (95\% CI) were calculated separately for each sex and by age, age at completion of education, country, occupational group, and occupational exposure to biologic dust, mineral dust, and gas or fumes. ${ }^{11}{ }^{12}$ The median is used for the central tendency for non-normally distributed variables such as daily cigarette consumption. Unadjusted group comparisons employed the $\chi^{2}$ and Kruskal-Wallis tests as appropriate. ${ }^{13}$ The Kruskal-Wallis test was utilised because of its robustness for non-normally distributed continuous data. Logistic modelling was employed to define the associations of various demographic characteristics with current smoking. Goodness of fit was assessed with the Hosmer-Lemeshow test. ${ }^{14}$

\section{RESULTS}

\section{Demographic characteristics}

Of the 14714 subjects, 14565 (99.0\%) provided information on current smoking status. Of these, 7003 (48.1\%) were male. Mean age of the study group was 32.7 years (standard deviation 6.9 years). There were $2072(14.1 \%)$ subjects who completed their education before age 16, 5881 (40.0\%) who completed education between ages 16 and 19 years of age (inclusive), and 4948 (33.6\%) who completed education at 20 years of age or older. The remaining 1813 (12.3\%) subjects did not respond to this question or had not yet completed their education. Current smoking was less prevalent among women than men $\left(34.6 v 39.4 \%, \mathrm{p}<0.0001, \chi^{2}\right.$ test $)$ and was highest in the 30-39 year old age category for both men and women. Median daily cigarette consumption among current smokers was higher in men than in women ( $17 v 13$ cigarettes per day, $\mathrm{p}<0.0001$, Kruskal-Wallis test). Smoking prevalence was highest among persons completing their education before age 16 (51.3\% among men and 43.4\% among women). There was an approximate twofold difference in smoking prevalence between countries.

\section{Occupation and smoking}

For men in occupational groups with at least 50 subjects, metal making and treating workers had the highest unadjusted current smoking prevalence (54.3\%), followed by construction and mining (53.7\%; table 1). Persons with no

Table 1 Smoking prevalence by current occupational group and sex in the European Community Respiratory Health Survey, 1992-93

\begin{tabular}{|c|c|c|c|c|c|c|}
\hline \multirow[b]{2}{*}{ Occupational group } & \multicolumn{3}{|l|}{ Men } & \multicolumn{3}{|l|}{ Women } \\
\hline & $\begin{array}{l}\text { Subjects } \\
(\mathrm{n})\end{array}$ & $\begin{array}{l}\text { Current smoking } \\
\text { prevalence, } \%(95 \% \mathrm{Cl})\end{array}$ & $\begin{array}{l}\text { Median } \\
\text { cpd }\end{array}$ & $\begin{array}{l}\text { Subjects } \\
(\mathrm{n})\end{array}$ & $\begin{array}{l}\text { Current smoking } \\
\text { prevalence, } \%(95 \% \mathrm{Cl})\end{array}$ & $\begin{array}{l}\text { Median } \\
\text { cpd }\end{array}$ \\
\hline Professional, administrative, clerical, service & 3522 & 35.4 (33.8 to 37.0$)$ & 15 & 4879 & 33.6 (32.3 to 35.0$)$ & 13 \\
\hline Cleaners & 77 & 48.1 (36.5 to 59.7$)$ & 16 & 288 & 50.7 (44.8 to 56.6$)$ & 15 \\
\hline Hairdressers & 10 & 50.0 (18.7 to 81.3$)$ & 10 & 88 & 46.6 (35.9 to 57.5$)$ & 15 \\
\hline Nurses & 38 & $36.8(21.8$ to 54.0$)$ & 13.5 & 383 & $30.3(25.7$ to 35.2$)$ & 10 \\
\hline Farmers, farm workers & 38 & 26.3 (13.4 to 43.1$)$ & 18.5 & 19 & $26.3(9.1 \text { to } 51.2)^{\prime}$ & 20 \\
\hline Agricultural workers & 105 & 43.8 (34.1 to 53.8 ) & 15 & 61 & 26.2 (15.8 to 39.1$)$ & 15 \\
\hline Wood workers & 157 & $33.8(26.4$ to 41.7$)$ & 15 & 7 & 71.4 (29.0 to 96.3$)$ & 10 \\
\hline Bakers & 39 & 48.7 (32.4 to 65.2$)$ & 20 & 27 & 37.0 (19.4 to 57.6$)$ & 20 \\
\hline Other food processors & 48 & $52.1(37.2$ to 66.7$)$ & 15 & 54 & $33.3(21.1$ to 47.5$)$ & 12.5 \\
\hline Laboratory technicians, assistants & 45 & $17.8(8.0$ to 32.1$)$ & 15 & 96 & 28.1 (19.4 to 38.2$)$ & 10 \\
\hline Plastics and rubber workers & 23 & $47.8(26.8$ to 69.4$)$ & 15 & 7 & 71.4 (29.0 to 96.3$)$ & 15 \\
\hline Chemical processors & 57 & 45.6 (32.4 to 59.3$)$ & 16 & 7 & 28.6 (3.7 to 71.0 ) & 9 \\
\hline Welders, solderers & 62 & 32.3 (20.9 to 45.3$)$ & 20 & 2 & 50.0 (12.6 to 98.7$)$ & 10 \\
\hline Metal making and treating & 127 & 54.3 (45.3 to 63.2 ) & 20 & 8 & 50.0 (15.7 to 84.3$)$ & 7 \\
\hline Other metal workers & 505 & 46.9 (42.5 to 51.4$)$ & 20 & 50 & $40.0(26.4$ to 54.8$)$ & 14.5 \\
\hline Electrical processors & 323 & 39.3 (34.0 to 44.9$)$ & 18 & 38 & $26.3(13.4$ to 43.1$)$ & 12.5 \\
\hline $\begin{array}{l}\text { Spray painters, other painters, and remainder } \\
\text { painting }\end{array}$ & 131 & 51.1 (42.3 to 60.0) & 20 & 53 & $39.6(26.5$ to 54.0$)$ & 10 \\
\hline Leather workers & 19 & 47.4 (24.4 to 71.1$)$ & 20 & 13 & 38.5 (13.9 to 68.4$)$ & 10 \\
\hline Textile and clothing & 54 & $37.0(24.3$ to 51.3$)$ & 18.5 & 133 & 42.1 (33.6 to 51.0$)$ & 15 \\
\hline Paper workers & 23 & $52.2(30.6$ to 73.2$)$ & 17.5 & 13 & $46.2(19.2$ to 74.9$)$ & 12.5 \\
\hline Printing workers & 64 & 48.4 (35.8 to 61.3$)$ & 20 & 24 & 29.2 (12.6 to 51.1$)$ & 8 \\
\hline Glass and ceramics workers & 24 & 58.3 (36.6 to 77.9$)$ & 19 & 9 & 44.4 (13.7 to 78.8$)$ & 20 \\
\hline Remainder non-metal/non-electrical processors & 104 & 48.1 (38.2 to 58.1$)$ & 20 & 76 & $38.2(27.2$ to 50.0$)$ & 15 \\
\hline Construction, mining & 246 & 53.7 (47.2 to 60.0$)$ & 20 & 9 & 44.4 (13.7 to 78.8$)$ & 12.5 \\
\hline Industrial drivers & 312 & $51.0(45.3$ to 56.6$)$ & 20 & 25 & 52.0 (31.3 to 72.2$)$ & 20 \\
\hline Remainder transport and storage & 151 & $51.0(42.7$ to 59.2$)$ & 20 & 58 & 44.8 (31.7 to 58.5$)$ & 20 \\
\hline $\begin{array}{l}\text { Occupation not stated, including housewife/ } \\
\text { husband and student }\end{array}$ & 141 & 30.5 (23.0 to 38.8$)$ & 15 & 560 & 34.6 (30.7 to 38.7$)$ & 12 \\
\hline Unclassified & 99 & 47.5 (37.3 to 57.8$)$ & 20 & 73 & 41.1 (29.7 to 53.2$)$ & 10 \\
\hline
\end{tabular}


Table 2 Smoking prevalence by current job exposures and sex in the European Community Respiratory Health Survey, 1992-93

\begin{tabular}{|c|c|c|c|c|c|c|}
\hline \multirow[b]{2}{*}{$\begin{array}{l}\text { Job } \\
\text { exposure }\end{array}$} & \multicolumn{3}{|l|}{ Men } & \multicolumn{3}{|l|}{ Women } \\
\hline & $\begin{array}{l}\text { Subjects } \\
\text { (n) }\end{array}$ & $\begin{array}{l}\text { Current smoking } \\
\text { prevalence, } \%(95 \% \mathrm{Cl})\end{array}$ & cpd & $\begin{array}{l}\text { Subjects } \\
\text { (n) }\end{array}$ & $\begin{array}{l}\text { Current smoking } \\
\text { prevalence, } \%(95 \% \mathrm{CI})\end{array}$ & cpd \\
\hline \multicolumn{7}{|c|}{ Biologic dust } \\
\hline None & 5363 & $39.4(38.1$ to 40.8$)$ & 18 & 5994 & 33.7 (32.5 to 34.9 ) & 12 \\
\hline Low & 783 & 44.6 (41.1 to 48.1$)$ & 20 & 884 & 43.3 (40.0 to 46.7$)$ & 15 \\
\hline High & 398 & 37.7 (32.9 to 42.7 ) & 18 & 182 & 31.3 (24.7 to 38.6$)$ & 15 \\
\hline \multicolumn{7}{|c|}{ Mineral dust } \\
\hline None & 4145 & 36.9 (35.4 to 38.4$)$ & 17 & 6127 & 33.7 (32.6 to 34.9$)$ & 13 \\
\hline Low & 1877 & 44.4 (42.2 to 46.7$)$ & 20 & 575 & 40.3 (36.3 to 44.5$)$ & 15 \\
\hline High & 522 & 48.3 (43.9 to 52.7 ) & 20 & 358 & $45.3(40.0$ to 50.6$)$ & 15 \\
\hline \multicolumn{7}{|c|}{ Gas or fumes } \\
\hline None & 3951 & 37.2 (35.7 to 38.7$)$ & 18 & 5276 & 33.5 (32.2 to 34.8 ) & 13 \\
\hline Low & 1900 & $42.4(40.2$ to 44.7$)$ & 20 & 1390 & 36.9 (34.4 to 39.5$)$ & 13 \\
\hline High & 693 & 48.8 (45.0 to 52.6 ) & 19.5 & 394 & 45.9 (40.9 to 51.0$)$ & 15 \\
\hline
\end{tabular}

stated occupation, including students, had the lowest smoking prevalence among men $(30.5 \%)$. For women in occupational groups with at least 50 subjects, cleaners had the highest unadjusted current smoking prevalence (50.7\%), followed by hairdressers (46.6\%). Agricultural workers had the lowest smoking prevalence among women (26.2\%). Median daily cigarette consumption among current smokers in the 28 occupational groups was $10-20$ for men and 7-20 for women.

\section{Job exposures and smoking}

The likelihood of current smoking increased directly with exposure to mineral dust and gas or fumes (table 2). This pattern held when adjusted for age category, sex, country, and age at completion of education. Because exposure status was assigned based on occupation rather than individual measurements, we did not include both occupational group and exposures in the same regression model to avoid multicollinearity. There was no clear pattern of current smoking prevalence for men or women according to biologic dust.

\section{Multivariate modelling}

Logistic regression models incorporating the main effects of occupational group, age group, age at completion of education category, and country were developed separately for each sex (table 3) and confirmed patterns evident in initial bivariate analyses, including associations with country and age. Professional/administrative and clerical workers served as the referent group because of the large number of subjects and relatively low smoking prevalence in this category. Other demographic factors associated with increased smoking included male sex and younger age at completion of education. Inclusion of age at completion of education resulted in reduction of the odds ratio for nearly all job categories, indicating its importance as a confounding factor.

Compared to the unadjusted job category specific smoking prevalence rankings and limiting consideration to job categories with at least 50 persons, multivariate adjustment did not alter the lowest prevalence job for men (occupation not stated, including housewife/husband and student, OR 0.39, 95\% CI 0.24 to 0.62 ) or for women (agricultural workers, OR $0.73,95 \%$ CI 0.40 to 1.34 ).

The highest adjusted odds ratio for smoking among men was in glass and ceramics workers (OR 3.89, 95\% CI 1.43 to 10.60). This job category also had the highest unadjusted smoking prevalence $(58.3 \%)$, but was not included in the unadjusted rankings reported above because there were fewer than 50 men in the job category. Excluding job categories with fewer than 50 male subjects, the five categories with the highest unadjusted prevalence of smoking (metal making and treating; construction, mining; spray painters, other painters, and remainder painting; industrial drivers; and remainder transport and storage) manifested increased odds ratios ranging from 1.32 (metal making and treating) to 1.82 (construction, mining). Odds ratios for all but metal making and treating were statistically significant.

The highest adjusted odds ratio for smoking among women was in plastics and rubber workers (OR 3.70, 95\% CI 0.7 to 19.33). This job category also had the highest unadjusted smoking prevalence $(71.4 \%)$, but was not included in the unadjusted rankings reported above because there were fewer than 50 women in the job category. Excluding job categories with fewer than 50 female subjects, the five categories with the highest unadjusted prevalence of smoking (cleaners; hairdressers; remainder transport and storage; textile and clothing; unclassified) manifested odds ratios ranging from 1.04 (textile and clothing) to 1.65 (unclassified). Only for cleaners was the odds ratio elevation statistically significant (OR $1.48,95 \%$ CI 1.14 to 1.90 ).

\section{DISCUSSION}

We report here the results of our analysis of smoking prevalence in various occupations based on the ECRHS data. Increased smoking prevalence was associated with male sex and lower educational attainment as seen in other studies. In addition, significant variation occurred between countries, consistent with earlier observations. ${ }^{15}$ We observed the highest smoking prevalences among metal workers, and construction and mining workers for men, and among cleaners and hairdressers for women. Lowest rates were seen among farmers and farm workers, welders and solderers, and those without a stated occupation, including housewives/husbands and students. Significant variation in prevalence among occupational groups persisted after multivariate adjustment for age, age at completion of education, and country.

Current smoking was increased among persons with jobs associated with higher exposures to mineral dusts or gases and fumes. Because occupational dust exposures may interact multiplicatively with smoking to cause adverse respiratory health outcomes, ${ }^{16}$ this finding underscores the importance of tobacco control for groups with occupational dust exposures. Previous work has shown that persons with occupational airborne exposures may not be more likely than unexposed smokers to receive advice on smoking cessation. ${ }^{17}$

Studies of smoking among occupational groups in the USA have documented patterns similar to those seen here of increased prevalence among manual and trade occupations (for example, among "blue collar" workers such as transportation operators, labourers, craft workers) in comparison to 


\begin{tabular}{|c|c|c|c|c|}
\hline \multirow[b]{2}{*}{ Factor } & \multicolumn{2}{|l|}{ Men } & \multicolumn{2}{|l|}{ Women } \\
\hline & Odds ratio & $95 \% \mathrm{Cl}$ & Odds ratio & $95 \% \mathrm{Cl}$ \\
\hline \multicolumn{5}{|l|}{ Age category (y) } \\
\hline $20-29$ & 1.00 & Referent & 1.00 & Referent \\
\hline $30-39$ & 1.25 & 1.10 to 1.41 & 1.00 & 0.89 to 1.13 \\
\hline $40-44$ & 1.04 & 0.90 to 1.21 & 0.71 & 0.61 to 0.83 \\
\hline \multicolumn{5}{|l|}{ Age on completion of education (y) } \\
\hline$\geqslant 20$ & 1.00 & Referent & 1.00 & Referent \\
\hline $16-19$ & 2.10 & 1.74 to 2.54 & 2.04 & 1.71 to 2.42 \\
\hline$\leqslant 15$ & 1.54 & 1.36 to 1.76 & 1.65 & 1.46 to 1.86 \\
\hline \multicolumn{5}{|l|}{ Country } \\
\hline Sweden & 1.00 & Referent & 1.00 & Referent \\
\hline Belgium & 2.28 & 1.76 to 2.94 & 0.98 & 0.78 to 1.24 \\
\hline Germany & 3.01 & 2.44 to 3.73 & 1.34 & 1.09 to 1.64 \\
\hline Spain & 4.30 & 3.42 to 5.36 & 1.48 & 1.20 to 1.82 \\
\hline Ireland & 1.83 & 1.31 to 2.55 & 1.40 & 1.01 to 1.94 \\
\hline Italy/Switzerland & 2.06 & 1.57 to 2.69 & 0.77 & 0.58 to 1.02 \\
\hline Netherlands & 2.79 & 2.20 to 3.53 & 1.32 & 1.05 to 1.65 \\
\hline United Kingdom & 1.08 & 0.83 to 1.40 & 0.63 & 0.50 to 0.80 \\
\hline Iceland & 2.66 & 1.93 to 3.66 & 1.43 & 1.05 to 1.94 \\
\hline Norway & 3.20 & 2.38 to 4.29 & 1.87 & 1.41 to 2.48 \\
\hline New Zealand & 0.77 & 0.59 to 1.02 & 0.57 & 0.44 to 0.73 \\
\hline USA & 1.01 & 0.67 to 1.52 & 0.41 & 0.27 to 0.63 \\
\hline Australia & 1.18 & 0.86 to 1.61 & 0.60 & 0.44 to 0.81 \\
\hline \multicolumn{5}{|l|}{ Occupational group } \\
\hline Professional/administrative, clerical & 1.00 & Referent & 1.00 & Referent \\
\hline Cleaners & 1.60 & 0.97 to 2.64 & 1.48 & 1.14 to 1.90 \\
\hline Hairdressers & 1.01 & 0.26 to 3.90 & 1.46 & 0.93 to 2.28 \\
\hline Nurses & 1.06 & 0.49 to 2.29 & 0.86 & 0.67 to 1.12 \\
\hline Farmers, farm workers & 0.76 & 0.35 to 1.62 & 0.67 & 0.21 to 2.12 \\
\hline Agricultural workers & 1.44 & 0.93 to 2.22 & 0.73 & 0.40 to 1.34 \\
\hline Wood workers & 0.82 & 0.57 to 1.20 & 3.59 & 0.62 to 20.76 \\
\hline Bakers & 1.80 & 0.88 to 3.68 & 0.84 & 0.37 to 1.88 \\
\hline Other food processors & 1.71 & 0.93 to 3.12 & 0.75 & 0.42 to 1.35 \\
\hline Laboratory technicians, assistants & 0.45 & 0.18 to 1.11 & 0.87 & 0.52 to 1.45 \\
\hline Plastics and rubber workers & 1.44 & 0.61 to 3.42 & 3.70 & 0.71 to 19.33 \\
\hline Chemical processors & 0.95 & 0.54 to 1.65 & 0.59 & 0.11 to 3.11 \\
\hline Welders, solderers & 0.72 & 0.41 to 1.28 & 2.20 & 0.14 to 35.52 \\
\hline Metal making and treating & 1.32 & 0.90 to 1.93 & 1.19 & 0.29 to 4.84 \\
\hline Other metal workers & 1.43 & 1.16 to 1.76 & 1.38 & 0.76 to 2.48 \\
\hline Electrical processors & 1.03 & 0.80 to 1.33 & 0.51 & 0.24 to 1.10 \\
\hline Spray painters, other painters, and remainder painting & 1.81 & 1.24 to 2.65 & 1.06 & 0.59 to 1.90 \\
\hline Leather workers & 1.64 & 0.60 to 4.50 & 0.93 & 0.30 to 2.92 \\
\hline Textile and clothing & 0.77 & 0.42 to 1.43 & 1.04 & 0.71 to 1.52 \\
\hline Paper workers & 1.54 & 0.66 to 3.60 & 1.27 & 0.42 to 3.87 \\
\hline Printing workers & 1.41 & 0.83 to 2.39 & 0.79 & 0.32 to 1.96 \\
\hline Glass and ceramics workers & 3.89 & 1.43 to 10.60 & 1.07 & 0.18 to 6.26 \\
\hline Remainder non-metal/non-electrical processors & 1.29 & 0.82 to 2.01 & 1.09 & 0.66 to 1.81 \\
\hline Construction, mining & 1.82 & 1.36 to 2.43 & 1.17 & 0.27 to 5.05 \\
\hline Industrial drivers & 1.71 & 1.33 to 2.21 & 1.54 & 0.65 to 3.67 \\
\hline Remainder transport and storage & 1.79 & 1.25 to 2.55 & 1.46 & 0.73 to 2.91 \\
\hline Occupation not stated, including housewife/husband and student & 0.39 & 0.24 to 0.62 & 0.85 & 0.69 to 1.05 \\
\hline Unclassified & 1.86 & 1.20 to 2.87 & 1.65 & 0.98 to 2.76 \\
\hline
\end{tabular}

*Model incorporates main effects for the factors shown; Hosmer to Lemeshow $\mathrm{p}=0.24$ (men), $\mathrm{p}=0.26$ (women).

professional or other "white collar" groups. ${ }^{467}$ In general, the gap between blue collar and white collar groups in the USA has widened in recent decades. ${ }^{\text {? }}$

The public health importance of considering occupation in the context of smoking prevalence is evident in several areas. First, occupation is a strong correlate of smoking, exhibiting odds ratios comparable to those seen for age, sex, age at completion of education, and nationality. Occupational associations persist after adjustment for these demographic factors. Thus, knowledge of occupation is helpful in identifying high prevalence groups for prevention programmes.

Second, the workplace may play an important role as part of a comprehensive public health approach to tobacco control. ${ }^{18}$ Workplace restrictions represent a barrier to smoking behaviour and may motivate employees to quit smoking. Workplace programmes should also include access to assistance programmes for persons wishing to quit smoking. Although recent efficacy studies have raised questions regarding the benefit of workplace smoking restrictions with respect to smoking cessation, ${ }^{19}$ they are clearly successful when enforced in reducing occupational exposure to environmental tobacco smoke. Protection from involuntary exposure to environmental tobacco smoke at work and in public places has been the subject of World Health Organisation resolutions (for example, WHA39.14, 1986). ${ }^{8}$

A major strength of this study is that it provides to our knowledge the first comprehensive data on smoking prevalence and cigarette consumption by occupation for the European Union. The study utilised data from a large random sample of the populations in participating centres and countries. Thus, the results are likely to represent fairly the underlying smoking prevalence patterns in participating locales.

Limitations of the study include low numbers of subjects in some job categories, its cross sectional nature, and that the data represent subject reports rather than objectively validated data. Selection bias may also affect our results. In particular, 
subjects with poor health may have been more likely than healthy persons to participate in this health research study. To the extent that poorer health is caused by smoking, one would expect to see a higher smoking prevalence in the study sample than in the population at large. This may explain why we observed somewhat higher national smoking prevalences than reported in other studies. ${ }^{15}$

Finally, the sample did not include persons older than 44 years of age or teenagers. The latter group is an important target for tobacco merchants, because addiction at an early age will provide long term customers. Public health advocates are also strongly focused on adolescents for similar reasons. Further research should examine tobacco use in this group because of the potential for adverse health outcomes-and their prevention - as the adolescent cohort ages.

Occupational and other patterns observed here may be affected by confounding. For example, age at completion of education was associated with current smoking prevalence, and adjustment for this factor reduced associations with occupation. Age at completion of education is a proxy for educational attainment, in that a young age of completion implies low educational attainment. High educational level has been associated with low prevalence of smoking and low occupational airborne exposures. ${ }^{21}$

Confounding with age at completion of education or other factors does not seriously affect the public health utility of the results. These data can be used to identify high smoking prevalence groups to target for anti-tobacco efforts; it is of lesser importance whether the high smoking prevalence is independently associated with the occupation or is in part caused by confounding by other variables. However, because age at completion of education was independently associated with smoking, this factor could also be used to identify groups for tobacco control efforts.

The results from this study can provide important information for targeting prevention programmes. In particular, occupations with high smoking prevalence and large numbers of employees are likely to yield the greatest population benefit with respect to reduction of smoking and workplace exposure to environmental tobacco smoke. Based on these data, such occupational groups include metal workers, construction workers, miners, and cleaners, among others. In addition, these data provide a valuable benchmark for assessing future efforts at tobacco control. As tobacco control efforts gain momentum in the European Union ${ }^{15}$ subsequent surveys can document changes in smoking behaviour among the affected population.

\section{ACKNOWLEDGEMENTS}

Grant support: The European Commission supported the coordination of this work. The following grants helped to fund the local studies: Australia: Allen and Hanbury's. Belgium: Belgian Science Policy Office, National Fund for Scientific Research. Germany: GSF, and the Bundesminister für Forschung und Technologie, Bonn. Italy: Ministero dell'Universita e della Ricerca Scientifica e Tecnologica, CNR, Regione Veneto grant RSF n. 381/05.93. Netherlands: Ministry of Welfare, Public Health and Culture. New Zealand: Asthma Foundation of New Zealand, Lotteries Grant Board, Health Research Council of New Zealand. Norway: Norwegian Research Council project no. 101422/ 310. Spain: Ministerio Sanidad y Consumo FIS grants \#91/0016060/ 00E-05E., \#92/0319, \#93/0393, CIRIT 1999SGR00241, Hospital General de Albacete, Hospital General Juan Ramón Jiménez, Consejeria de Sanidad Principado de Asturias. Sweden: The Swedish Medical Research Council, the Swedish Heart Lung Foundation, the Swedish Association against Asthma and Allergy. Switzerland: Swiss National Science Foundation grant 4026-28099. United Kingdom: National Asthma Campaign, British Lung Foundation, Department of Health, South Thames Regional Health Authority. USA: United States Department of Health, Education and Welfare Public Health Service Grant \#2 S07 RR05521-28.

Coordination of the ECRHS: Department of Public Health Medicine, Guy's and St Thomas's medical and dental school, London, UK: P Burney, S Chinn, C Luczynska, D Jarvis, E Lai, J Potts.
Participating centres providing occupational information: Australia: M Abramson, J Kutin (Melbourne); Belgium: P Vermeire, F van Bastelaer (Antwerp South, Antwerp Central); Germany: H Magnussen, D Nowak (Hamburg); HE Wichmann, J Heinrich (Erfurt); Iceland: T Gislason, D Gislason (Reykjavik); Ireland: J Prichard, S Allwright, D MacLeod (Dublin); Italy: M Bugiani, C Bucca, C Romano (Turin); R de Marco lo Cascio, C Campello (Verona); A Marinoni, I Cerveri, L Casali, L Perfetti (Pavia); Netherlands: B Rijcken, JP Schouten, M Kerkhof, HM Boezen (Groningen, Bergen op Zoom, Geleen); New Zealand: J Crane, S Lewis, N Pearce (Wellington, Christchurch, Hawkes Bay); Norway: A Gulsvik, E Omenaas (Bergen); Spain: JM Antó, J Sunyer, J Soriano, M Kogevinas, A Tobías, J Roca (Barcelona); N Muniozguren, J Ramos González, A Capelastegui (Galdakao); J Martínez-Moratalla, E Almar (Albacete); J Maldonado Pérez, A Pereira, J Sánchez (Huelva); J Quirós, I Huerta (Oviedo); Sweden: G Boman, C Janson, E Björnsson (Uppsala); L Rosenhall, E Norrman B Lundbäck (Umea); N Lindholm, P Plaschke, K Torén (Göteborg); Switzerland: N Künzli (Basel); United Kingdom: R Hall (Ipswich), B Harrison (Norwich), J Stark (Cambridge); USA: S Buist, W Vollmer, M Osborne (Portland).

Job exposure matrix: H Kromhout, R Vermeulen (Utrecht, Netherlands).

...................

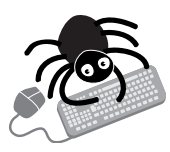

The appendix can be viewed on the OEM website (www.occenvmed.com/supplemental)

\section{Authors' affiliations}

S A McCurdy, Department of Epidemiology and Preventive Medicine, University of California, Davis, USA

J Sunyer, J-P Zock, J M Antó, M Kogevinas, Respiratory and Environmental Health Research Unit, Institut Municipal d'Investigació Mèdica (IMIM), E08003 Barcelona, Spain

\section{REFERENCES}

1 US Department of Health Education and Welfare. Smoking and health. Report of the Advisory Committee to the Surgeon General of the Public Health Service. PHS publication no. 1103. Washington, DC: US Department of Health, Education, and Welfare, Public Health Service, 1964.

2 US Department of Health and Human Services. Reducing tobacco use. A report of the Surgeon General. Report no. S/N

017-001-00544-4. Atlanta, GA: US Department of Health and Human Services, Centers for Disease Control and Prevention, National Center for Disease Prevention and Health Promotion, Office of Smoking and Health, 2000.

3 Brenner H, Born J, Novak P, et al. Smoking behavior and attitude toward smoking regulations and passive smoking in the workplace. A study among 974 employees in the German metal industry. Prev Med 1997; 26:138-43.

4 Bang KM, Kim JH. Prevalence of cigarette smoking by occupation and industry in the United States. Am J Ind Med 2001;40:233-9.

5 Brackbill R, Frazier T, Shilling S. Smoking characteristics of US workers, 1978-1980. Am J Ind Med 1988;13:5-41.

6 Leigh JP. Occupations, cigarette smoking, and lung cancer in the epidemiological follow-up to the NHANES I and the California Occupational Mortality Study. Bull N Y Acad Med 1996;73:370-97.

7 Nelson DE, Emont SL, Brackbill RM, et al. Cigarette smoking prevalence by occupation in the United States. A comparison between 1978 to 1980 and 1987 to 1990. J Occup Med 1994;36:516-25.

8 World Health Organisation. Tobacco or health: a global status report. Geneva, Switzerland: World Health Organisation, 1997.

9 Burney PG, Luczynska C, Chinn S, et al. The European Community Respiratory Health Survey. Eur Respir J 1994;7:954-60.

10 Office of Population Censuses and Surveys. Classification of occupations. London: HMSO, 1980.

11 Kogevinas M, Anto JM, Sunyer J, et al. Occupational asthma in Europe and other industrialised areas: a population-based study. European Community Respiratory Health Survey Study Group. Lancet 1999;353:1750-4.

12 Sunyer J, Kogevinas $M$, Kromhout $H$, et al. Pulmonary ventilatory defects and occupational exposures in a population-based study in Spain. Spanish Group of the European Community Respiratory Health Survey. Am J Respir Crit Care Med 1998;157:512-17.

13 Armitage P, Berry G, Matthews JNS. Statistical methods in medical research, 4th edn. London: Blackwell Science Ltd, 2002. 
14 Hosmer DW, Taber S, Lemeshow S. The importance of assessing the fit of logistic regression models: a case study. Am J Public Health 1991;81:1630-5.

15 World Health Organisation. It can be done: a smoke-free Europe. Report of the First European Conference on Tobacco Policy. Geneva, Switzerland: WHO Regional Publications, 1990:67.

16 Zock JP, Sunyer J, Kogevinas M, et al. Occupation, chronic bronchitis, and lung function in young adults. An international study. Am J Respir Crit Care Med 200 1;163:1572-7.

17 Bakke P, Gulsvik A, Eide GE, et al. Smoking habits and lifetime occupational exposure to gases or dusts, including asbestos and quartz, in a Norwegian community. Scand J Work Environ Health $1990 ; 16: 195-202$
18 Gerlach KK, Shopland DR, Hartman AM, et al. Workplace smoking policies in the United States: results from a national survey of more than 100,000 workers. Tob Control 1997;6:199-206.

19 Sorensen G, Thompson B, Glanz K, et al. Work site-based cancer prevention: primary results from the Working Well Trial. Am J Public Health 1996;86:939-47.

20 Glasgow RE, Terborg JR, Hollis JF, et al. Take heart: results from the initial phase of a work-site wellness program. Am J Public Health 1995;85:209-16.

21 Bakke PS, Hanoa R, Gulsvik A. Educational level and obstructive lung disease given smoking habits and occupational airborne exposure: a Norwegian community study. Am J Epidemiol 1995;141:1080-8.

\section{Applications are invited for the post of}

\section{Editor}

\section{Occupational and Environmental Medicine}

OEM is one of the premier journals in occupational and environmental medicine. We now seek an editor who can increase its scientific and international reputation while maintaining its relevance to practising occupational physicians worldwide. Applications from specialists in any branch of occupational or environmental medicine are invited. Applications from outside the UK are encouraged and joint applications from two or more individuals willing to act as a team are welcomed.

Full editorial support and training will be provided. The journal will fund any necessary locum requirements. The successful applicant(s) will be free to select his/her own team of associate editors and board members.

Closing date for applications is 1 September 2003. Interviews will be held on Monday, 6 October 2003. It is envisaged that the outgoing editor will gradually hand over during the fourth quarter of 2003 and the successful candidate will officially take up the post of editor in January 2004.

Further details of the post can be discussed with the publishing director, Mrs Alex Williamson and/or the retiring editor Dr Anne Cockcroft (email: acockcroft@bmigroup.com). A job description is available on request from Mrs Williamson.

Applications should be sent to Mrs Alex Williamson, BM Publishing Group, BMA House, Tavistock Square, London WC1H 9JR, UK. Tel: +44 (0)20 7383 6069/6169; Fax: +44 (0)20 7383 6668; email: awilliamson@bmigroup.com.

\section{$\mathrm{BMJ}$}

